\title{
PENEGAKAN HUKUM TERHADAP PELANGGARAN PENGGUNAAN TELEPHONE SELULAR SAAT BERKENDARA
}

\author{
I Putu Raditya, Ida Ayu Putu Widiati, I Made Minggu Widyantara \\ Fakultas Hukum Universitas Warmadewa, Denpasar-Bali, Indonesia
}

\begin{abstract}
Abstrak
Telepon Selular ialah perangat telekomunikasi yang mampu menghubungkan orang dengan orang lain yang terhalang jarak. Penggunaannya pun kini sangat menjadi prioritas bagi kebanyakan orang. Namun, tingkat kecelakaan lalu lintas yang diakibatkan oleh pengendara yang mengendarai kendaraannya sembari menggunakan telepon pun semakin bertambah. Berhubungan dengan hal tersebut diatas maka akan dibahas mengenai pengaturan terhadap penggunaan telepon selular saat berkendara dan penegakan hukum bagi pengendara yang melakukan pelanggaran terhadap penggunaan telepon selular saat berkendara. Penulisan metode yang digunakan dalam penulisan ini adalah metode hukum normatif yang memakai teknik pengumpulan bahan hukum berupa study dokumen dan memakai sumber bahan hukum primer seperti perundang-undangan dan bahan hukum sekunder seperti buku-buku hukum yang kemudian diuraikan secara deskriptif guna memperoleh kesimpulan akhir. Hasil penelitian ini menunjukkan bahwa pelanggaran terhadap penggunaan telepon selular yang sudah diterangkan bahwa dalam berkendara bisa menghilangkan konsentrasi hingga menyebabkan terjadinya suatu kecelakaan dan bahkan hingga menyebabkan kematian, diancam dengan pidana kurungan dan denda sebagaimana diatur dalam Undang-Undang Nomo 22 Tahun 2009 tentang Lalu Lintas dan Angkutan Jalan. Untuk upaya penegakan hukum dari pelaggaran penggunaan telepon selular, diperlukan pemberian pemahaman kepada masyarakat dari yang usia remaja hingga dewasa tentang bahaya dan dampak dari penggunaan telepon selular saat berkendara, sehingga dapat terciptanya keselamatan saat berkendara bersama pengguna jalan umum lainnya.
\end{abstract}

Kata Kunci: Lalu Lintas; Pelanggaran; Telepon Selular

\begin{abstract}
Cell phone is a telecommunications device that enables people to connect with others who are separated by distance. Its usage is now a priority for most people. The level of traffic accidents caused by motorists who drive their vehicles while using the telepon, however, is increasing. Refered to the background above, this study focused on describing the regulation of the use of cell phone while driving and law enforcement for motorists who violate the use of cellular phone while driving. The writing method used in this writing was a normative legal method that used legal material collection technique in the form of study documents and used primary legal material sources such as legislation and secondary legal materials such as legal books which were then elaborated descriptively to obtain final conclusions. The results of this study indicated that violations of the use of cell phone that have been explained that in driving can eliminate concentration to cause an accident and even to cause death, threatened with imprisonment and fines as regulated in Law No. 22 of 2009 concerning Traffic and Road Transportation. For law enforcement efforts to prevent the use of cell phones, it is necessary to provide an understanding to the public from adolescence to adulthood about the dangers and impacts of using cell phones while driving, so that safety can be created while driving with other public road users.
\end{abstract}

Keywords: Traffi; Violations; Cellular Phones

\section{PENDAHULUAN}

Di Indonesia telepon selular yang sering dikenal dengna ponsel atau HP adalah perangkat telekomunikasi elektronik yang memiliki kemampuan dasar yang sama dengan telepon konvensional saluran tetap tetap dapat dibawa kemana saja. Terdapat perbedaan antara telepon konvensional dengan telepon masa kini, yaitu tidak adanya fasilitas untuk mengakses sosial media pada telepon konvensional. Beberapa tahun belakangan ini jumlah pengguna telepon terus menunjukkan peningkatan yang sangat signifikan (Chuzaimah, Mabruroh, \& Dihan, 2010; Yusrizal, 2016). Sehingga penggunaannya pun tidak mengenal waktu, keadaan dan situasi sekitar pada penggunaannya dalam kehidupan sehari-hari. 
Dalam kehidupan sehari-hari alat transportasi yang lebih mudah digunakan dan praktis pemakaian yang mampu membawa kita ketempat tujuan adalah kendaraan roda dua atau yang sering disebut sepeda motor. Kendaraan dibagi menjadi dua macam yaitu kendaraan umum dan kendaraan pribadi (Tahir, 2005). Kendaraan umum adalah kendaraan yang digunakan untuk angkutan banyak baik untuk angkutan penumpang maupun barang, misalnya angkutan kota, bus, kereta api, kapal dan pesawat. Kendaraan pribadi merupakan kendaraan yang sehari-hari digunakan banyak orang untuk kepentingan pribadi. Kendaraan pribadi itu dapat berupa mobil dan motor yang sering digunakan masyarakat untuk mencapai tempat tujuan.

Dengan semakin bertambahnya jumlah kendaraan pribadi dan kebutuhan terhadap kendaraan umum, maka tak heran juga akan masalah yang dihadapi. Salah satu masalah yang paling banyak terjadi yaitu semakin bertambahnya angka kecelakaan di jalan raya. Angka kecelakaan yang semakin tinggi disebabkan oleh kondisi sarana prasarana jalan yang tidak baik, pengendara tidak menaati rambu rambu lalu lintas, kerusakan pada kendaraan, dan kurangnya konsentrasi pengguna jalan saat berkendara (Hidayah, 2017; Marsaid, Hidayat, \& Ahsan, 2013).

Kurangnya konsentrasi pengguna jalan saat berkendara itu terjadi karena faktor pengendara yang mengemudikan kendaraannya sembari bermain HP atau Ponsel atau telepon (Fatah, 2019; Setyowati, Firdaus, \& Rohmah, 2018). Ponsel merupakan salah satu alat komunikasi yang memicu terjadinya kecelakaan karena dapat mengalihkan konsentrasi pengguna jalan saat berkendara. Contohnya, pengguna jalan membaca dan membalas SMS atau Whatsapp atau sedang membuka situs-situs sosial media lainnya bahkan mungkin saja sedang memperbaharui status di sosial media saat berkendara. Hal tersebut juga didukung oleh banyaknya operator telekomunikasi yang memberikan layanan SMS pulsa serta telepon gratis, sehingga meningkatkan kencenderungan penggunaan ponsel yang tidak mengenal waktu dan tempat.

Di Indonesia larangan penggunaan ponsel saat berkendara telah diberlakukan. Aparat Penegak Hukum akan memberikan sanksi bagi pengendara yang menggunakan ponsel saat mengendarai kendaraan. Pasal 106 ayat (1) UU No. 22 Tahun 2009 tentang Lalu Lintas dan Angkutan Jalan menentukan bahwa setiap orang yang mengemudikan kendaraan bermotor di jalan wajib mengemudikan kendaraannya dengan wajar dan penuh konsentrasi.

Banyaknya kendaraan bermotor Merek terbaru yang hampir setiap tahun bahkan setiap bulan diproduksi secara masal oleh perusahaan pabrik pembuatan kendaraan bermotor yang ada di Indonesia maupun diluar negeri. Adapun yang langsung didatangkan dari luar negeri untuk diperjual belikan di Indonesia. Dengan demikian, hampir setiap jalan di Indonesia menjadi padat dan menjadi rentan terjadinya kecelakaan serta ditambah dengan kurangnya sarana prasarana jalan yang disediakan oleh Pemerintah Kota yang tidak diiringi dengan peningkatan jumlah kendaraan bermotor di jalan raya (Putri, 2014; Saputra, 2017).

Di dalam kehidupan sehari-hari maraknya kejadian kecelakaan di jalan raya memberikan cerminan bahwa betapa minimnya kesadaran masyarakat terhadap hukum untuk pengendara sepeda motor. Masih banyak orang-orang mengemudi sepeda motornya dengan tidak tertib dan taat pada rambu-rambu lalu lintas atau sering kali ugal-ugalan (Agreda, 2017; Doly, 2019). Diuraikan dalam UU No. 22 Tahun 2009 Tentang Lalu Lintas dan Angkutan Jalan khususnya di Pasal 58 menentukan bahwa "kendaraan hanya boleh dioperasikan dalam keadaan baik dan aman bagi pengemudinya dan bagi pihak lainnya". Maka dalam hal ini, setiap berkendara mestilah kita mengutamakan keselamatan di jalan raya.

Berdasarkan atas uraian di atas, fokus penelitian ini adalah mendeskripsikan bagaimana pengaturan terhadap penggunaan telepon selular saat berkendara dan bagaimana penegakkan hukum bagi pengendara yang melakukan pelanggaran terhadap penggunaan telepon selular saat berkendara.

\section{METODE PENELITIAN}

Penelitian ini didesain dengan menggunakan pendekatan penelitian hukum normatif. Pendekatan ini merupakan pendekatan penelitian hukum yang mengkaji hukum tertulis dari berbagai aspek. Metode pengumpulan bahan hukum yang berdasarkan dokumentasi, yaitu dengan pengkajian penelitian yang dilakukan melalui study kepustakaan (Mamudji, 2006). Sumber data penelitian ini adalah Kitab Undang-Undang Hukum Pidana, Undang-Undang Nomor 22 Tahun 2009 Tentang Tentang Lalu Lintas dan Angkutan Jalan, dan Peraturan Pemerintah Nomor 37 Tahun 2017 Tentang Keselamatan Lalu Lintas dan Angkutan Jalan. Beberapa bahan hukum baik bahan hukum primer dan bahan hukum 
sekunder dikumpulkan dan dikategorikan, sehingga dapat disusun secara sistematis. Penelitian ini juga menggunakan konsep-konsep hukum seperti sumber hukum fungsi hukum lembaga hukum. Kemudian, hasil analisis data penelitian ini disajikan secara deskriptif.

\section{HASIL DAN PEMBAHASAN}

\section{Pengaturan terhadap Penggunaan Telephone Selular saat Berkendara}

Telepon selular merupakan alat komunikasi utama masa kini yang berperan sangat penting di era masa kini. Telephone selular sangat bermanfaat dalam menjadikan pekerjaan seseorang menjadi lebih mudah, cepat dan praktis. Dalam penggunaan telepon selular pun kita harus berhati-hati baik dalam situasi dan kondisi kita sedang dalam perjalanan maupun dalam aktivitas apapun.

Lalu lintas memiliki kriteria dan keunggulan tersendiri dalam pelaksanaan ketertiban pengguna jalan. Oleh karena itu, perlu diketahui bahwa berkembangnya mobilitas sosial masyarakat memberikan dampak yang semakin pesat terhadap perkembangan teknologi dan ilmu pengetahuan. Mengetahui bahwa peranan utama transportasi sangatlah penting bagi kehidupan sehari-hari maka lalu lintas diciptakan dalam sistem transpotasi yang terpadu guna mewujudkan tersedianya jasa transportasi yang bersahaja dengan tingkat kebutuhan lalu lintas yang tertib, aman, nyaman, cepat, teratur, lancar, dan biaya yang terjangkau oleh masyarakat. Menurut Pasal 1 Undang-Undang Nomor 22 tahun 2009 lalu lintas didefinisikan sebagai laju gerak kendaraan dan orang dalam berlalu lintas di jalan.

Dalam berkendara tak banyak orang yang paham akan bahaya menggunakan telepon selular saat berkendara. Dalam Undang-Undang Nomor 22 Tahun 2009 tentang Lalu Lintas dan Angkutan Jalan ditegaskan dalam pasal 106 ayat 1 bahwa "setiap orang yang mengemudikan kendaraan bermotor di jalan wajib mengemudikan kendaraannya dengan wajar dan penuh konsentrasi". Dalam hal ini mengemudikan kendaraan dengan wajar dan penuh konsentrasi yang dimaksud adalah tidak mengemudikan kendaraan saat sedang sakit, sedang lelah, sedang dalam pengaruh minuman beralkohol, ataupum sedang menggunakan telepon selular.

Penggunaan telepon selular saat berkendara dapat menyebabkan hilangnya konsentrasi dalam berkendara, dan bisa menyebabkan kita mengalami kecelakaan (Nurdjanah \& Puspitasari, 2017). Tidak bisa dipungkiri lagi bahwa pada era modernisasi ini telepon selular digunakan dalam berbagai situasi dan kondisi dimana pun kita berada, contohnya penggunaan aplikasi Gojek. Gojek bekerja dengan menggunakan telepon selular saat berkendara, padahal menggunakan telepon selular saat berkendara dapat menyebabkan hilangnya konsentrasi saat mengemudi dan mengakibatkan kecelakaan.

Mengenai larangan penggunaan telepon selular saat berkendara secara spesifik tidak diatur dalam Undang-Undang No 22 Tahun 2009, tetapi pengendara yang menggunakan ponsel saat berkendara bisa terkena pasal 106 ayat 1 sebagaimana tersebut diatas. Sanksi terhadap pelanggaran pasal tersebut diatur dalam pasa 283 Undang-Undang No 22 Tahun 2009 yakni dengan denda maksimal Rp. 750.000.- (tujuh ratus lima puluh ribu rupiah) dan subside kurungan 3 bulan. Pemerintah juga berusaha keras untuk memperbarahui tindakan yang salah dalam berlalu lintas. Karena semakin berkembangnya zaman tentunya semakin banyak pula kelalaian-kelalaian yang dibuat oleh masyarakat luas. Selama peraturan yang dibuat pemerintah adalah demi berlalu lintas yang baik dan benar tentunya peraturan tersebut tidak ada salahnya.

Salah satu penyebab tingginya angka kecelakaan lalu lintas adalah kurangnya kesadaran masyarakat dalam berkendara seperti contohnya saat mengendarai sepeda motor banyak pengendara kurang focus. Ada juga pengendara yang semena-semana menyerobot pengendara lainnya sehingga menyebabkan pengendara lain tersenggol atau menyebabkan pengendara lain mengalami kecelakaan. Ada juga yang mengendarai sepeda motor sembari menelphone atau bermain telepon dan ada juga beberapa factor yang sangat mempengaruhi kecelakaan dalam berkendara itu yakni keadaan dijalan yang kurang memungkinkan seperti kondisi jalan yang kurang baik kondisi struktur jalan yang kurang memadai dan ditambah kondisi pengendara yang kurang fit dalam berkendara.

Semua perbuatan pidana yang tergolong pelanggaran diatur dalam buku III KUHP. Pelanggaran didefinisikan sebagai perbuatan yang bertentangan dengan keadilan terlepas apakah perbuatan itu diancam pidana dalan suatu peraturan undang-undang atau tidak. Menurut salah satu pendapat para ahli mengemukakan bahwa pelanggaran ialah kejahatan pada umumnya yang dilakukan dengan tanpa sengaja maupun dengan sengaja yang diancam dengan hukuman yang berat atas pelanggarannya dan 
ini didasarkan pada sifat lebih berat dari kejahatan (Poernomo, 2002). Menurut Wirjono Prodjodikoro pengertian pelanggaran adalah "overtredingen" atau pelanggaran berarti suatu perbuatan yang melanggar sesuatu dan berhubungan dengan hukum berarti tidak lain dari pada perbuatan melawan hukum (Wirjono, 2003).

Dari kalimat tersebut di atas jika dikaitkan dengan terjadinya sebuah kecelakaan lalu lintas yang terjadi akibat pengemudi lalai dengan kurang hati- hatinya dalam berkendara yang diakibatkan oleh penggunaan telepon selular saat berkendara, pelaku bisa terjerat pasal tersebut dan atas kejadian tersebut pelaku juga mendapatkan hukuman yakni akan dijatuhi pidana berupa pidana penjara kurungan atau denda, dan selain itu dapat dijatuhi pidana tambahan berupa pencabutan Surat Izin Mengemudi atau ganti kerugian yang diakibatkan oleh tindak pidana lalu lintas.

Ketertiban berlalu lintas merupakan cerminan disiplin diri guna mewujudkan generasi bangsa yang memberikan contoh yang baik pada generasi lainnya. Pentingnya kita tahu dan memberitahukan kepada saudara kita terhadap bahaya penggunaan telepon selular saat berkendara agar kita maupun saudara kita terbebas dari marabahaya yang dapat menyebabkan kita sampai kehilangan orang- orang terdekat kita. Oleh karena itu, untuk mengantisipasi terjadinya pelanggaran lalu lintas, masyarakat diharapkan dapat mengetahui dan melaksanakan serta patuh terhadap peraturan perundang-undangan yang berlaku yang diterapkan oleh seluruh penegak hukum untuk kepentingan bersama.

\section{Penegakan Hukum bagi Pengendara yang Melakukan Pelanggaran terhadap Penggunaan Telephone Selular saat Berkendara}

Penegakan Hukum ialah upaya ditegakannya keadilan yang diterbitkan melalui norma- norma hukum yang dijadikan sebagai pedoman berkehidupan dan bermasyarakat yang oleh aparat penegak hukum diciptakan demi mencapainya tujuan keamanan dan ketentraman. Penegakan hukum adalah proses di lakukannya upaya untuk tegaknya atau berfungsinya norma-norma hukum secara nyata sebagai pedoman prilaku dalam hubungan-hubungan hukum dalam kehidupan bermasyarakat dan bernegara. Penegakan hukum dilakukan dengan penindakan hukum menurut urutan berikut (Mertokusumo, 1986).

1. Penganjuran peneguran terhadap setiap terjadinya insiden lalu lintas ringan.

2. Terhadap kesalahan yang diperbuat terdapat tanggung jawab tertentu yang wajib dipatuhi seperti ganti rugi pidana denda.

3. Jika kesalahan tersebut merupakan pelanggaran hukum atas adat setempat maka sanksi atas tindakan itu adalah pengucilan maupun hukuman-hukuman yang berada dalam hukum setempat.

4. Dikenai sanksi fisik yaitu sanksi pidana penjara sanksi pidana mati.

Pelaksanaan hukum dapat terjadi karena pelanggaran hukum, yaitu dengan menegakan hukum tersebut dengan bantuan aparat penegak hukum dalam meminimalisir dampak kecelakaan yang terjadi akibat pelanggaran yang dilakukan oleh sipelanggar. Norma-norma hukum dalam penyelenggaraan lalu lintas dan angkutan jalan telah diatur dan ditegaskan dalam UU No. 22 Tahun 2009 tentang Lalu Lintas dan Angkutan Jalan menentukan bahwa semua orang yang mengendarai kendaraan bermotor di jalan harus mengendarai kendaraannya dengan hati-hati dan penuh konsentrasi. Dari pengertian diatas mengaplikasikan ketentuan sanksi pidana dalam kasus kealpaan untuk pengendara kendaraan yang berakibat terjadinya insiden lalu lintas dimana terdapat pada pasal-pasal yang berkaitan dengan kealpaan.

Di setiap pelanggaran yang dilakukan baik pelanggaran berat maupun ringan pasti memiliki sanksi yang tegas sesuai dengan pelanggarannya. Sanksi adalah tindakan-tindakan hukum yang memaksa seseorang untuk menaati ketentuan undang-undang apabila terjadi sebuah pelanggaran yang dibuat oleh si pelaku kejahatan. Sanksi bersifat memaksa dan tidak pandang balu. Sanksi Pidana adalah sebuah ganjaran dari sebab akibat sebab yaitu perkaranya dan akibat merupakan sanksinya mereka ikut serta akan mendapatkan hukuman dipenjara maupun dikenai sanksi lain dari aparat polisi (Andrisman, 2009)

Dalam Kitab Undang-Undang Hukum Pidana (KUHP) Pidana terbagi atas 2 (dua) bagian yakni Pidana Pokok dan Pidana Tambahan. Tujuan pemidanaan disetiap tindakan pelanggaran yang dibuat oleh sipelanggar adalah guna untuk memberikan efek jera pada si pelanggar agar tidak mengulaki kesalahan yang sama untuk kesekian kalinya. Selain bertujuan demikian pemidanaan juga bertujuan untuk mencegah dilakukannya kejahatan pada masa yang akan dating. Tak banyak juga pertentangan 
yang timbul menyinggung makna pidana yaitu mereka yang berpendapat bahwa pidana sebagai alat pembalasan atau hanya sebatas teori hukum guna menjalankan ketertiban sosial dalam kehidupan bermasyarakat.

Diera Modernisasi saat ini alat komunikasi seperti telepon selular merupakan kebutuhan pokok dalam menyambung kehidupan. Dalam penggunaan telepon selular pun kita harus berhati-hati baik dalam situasi dan kondisi kita sedang dalam perjalanan maupun dalam aktivitas manapun. Dimanapun kapanpun dan setiap saat pun telepon selular memiliki peran penting sebagai alat komunikasi dan alat untuk bekerja.

Banyak pengendara yang bermain telepon selular sembari berkendara, sehingga dampaknya bisa terjadi hilangnya konsentrasi jika terdapat pengendaran lain mengalami kelalaian dalam berkendara (out of control) dan kita yang sedang mengendarai sepeda motor sembari bermain telepon selular mengalami kecelakaan dan menambrak pengendara lainnya. Inilah yang dimaksud dalam pasal 106 ayat $1 \mathrm{UU}$ Nomor 22 Tahun 2009 yakni setiap orang yang berkendara menggunakan kendaraan dijalan raya diharuskan agar mengendarai kendaraannya dengan hati-hati dan penuh konsentrasi serta ditegaskan pula dalam UU Lalu Lintas dan Angkutan Jalan Pasal 234 menentukan dimana pengandara yang terutama mempunyai kendaraan wajib bertanggung jawab atas keselamatannya.

Sebagaimana yang kita ketahui bahwa menggunakan telepon selular dalam berkendara bisa memberikan dampak yang berbahaya bagi pengguna jalan lainnya. Pengaturan mengenai larangan penggunaan telepon selular dalam berkendara terdapat dalam KUHP Pasal 359 yang menentukan bahwa karena kealpaannya mengakibatkankan hilangnya nyawa seseorang. Meninggalnya seseorang tersebut sama sekali tidak diinginkan si pengendara, namun meninggalnya seseorang tersebut diakibatkan kurangnya konsentrasi dari pengendara tersebut." Terjadinya sebuah kecelakaan lalu lintas yang terjadi akibat pengemudi lalai, kurang hati-hatinya dalam berkendara yang diakibatkan oleh penggunaan telepon selular saat berkendara, pelaku bisa terjerat pasal tersebut. Dan, atas kejadian tersebut pelaku juga mendapatkan hukuman yakni akan dikenakan sanksi pidana, yaitu pidana penjara denda atau kurungan penjara. Selain itu, pelaku juga dapat dikenakan sanksi pidana tambahan seperti dicabutnya SIM atau membayar ganti rugi yang diakibatkan oleh tindak pidana lalu lintas. Pentingnya kita mengetahui setiap larangan yang diterapkan aparat penegak hukum guna keselamatan kita semua sebagai sesama pengguna jalan.

\section{SIMPULAN DAN SARAN}

\section{Simpulan}

Berdasarkan hasil penelitian yang diuraikan di atas, ada beberapa simpulan yang dapat dibuat, yaitu: pertama, pengaturan terhadap penggunaan telepon selular saat berkendara megacu pada UndangUndang Nomor 22 Tahun 2009 tentang Lalu Lintas dan Angkutan Jalan. Mengemudikan kendaraan dengan wajar dan penuh konsentrasi yang dimaksud adalah tidak mengemudikan kendaraan saat sedang sakit, sedang lelah, ataupun sedang dalam pengaruh minuman beralkohol. Mengenai larangan penggunaan telepon selular saat berkendara secara khusus tidak diatur dalam UU No 22 Tahun 2009 tetapi pengemudi yang mempergunakan telpon genggam saat berkendara dapat dikenai pasal 106 ayat 1 sebagaimana tersebut diatas. Kedua, sanksi terhadap pelanggaran pasal tersebut diatur dalam pasal 283 UU No 22 Tahun 2009 yakni dengan denda maksimal Rp. 750.000.- (tujuh ratus lima puluh ribu rupiah) dan subside kurungan 3 bulan.

\section{Saran}

Selain hasil penelitian yang dipaparkan dalam penelitian ini, ada beberapa saran juga yang perlu disampaikan kepada beberapa pihak, yaitu: pertama, bagi pihak penegak hukum untuk senantiasa memberikan penyuluhan kepada seluruh masyarakat dari yang usia remaja hingga dewasa terhadap bahaya dan dampak dari penggunaan telepon selular saat berkendara. Kedua, bagi pengendra untuk tidak menggunakan telepon seluler ketika sedang menjalankan kendaraan.

\section{DAFTAR PUSTAKA}

Agreda, S. (2017). Optimalisasi Penindakan Pelanggaran Lalu Lintas terhadao Modifikasi Kendaraan Bermotor yang Menyebabkan Kecelakaan Lalu Lintas di Wilayah Hukum Polres Purbalingga. Advances in Police Science Research Journal, 1(2), 521-566. Retrieved from 
http://berkas.dpr.go.id/puslit/files/info_singkat/Info Singkat-XI-11-I-P3DI-Juni-2019-208.pdf

Andrisman, T. (2009). Asas-Asas dan Dasar Aturan Hukum Pidana Indonesia. Bandar Lampung: Unila.

Chuzaimah, Mabruroh, \& Dihan, F. N. (2010). Smarphone: Antara Kebutuhan dan E-Lifestyle. Journal of Petrology, 3(1), 312-321. https://doi.org/10.1017/CBO9781107415324.004

Doly, D. (2019). Kesadaran Hukum Berlalu Lintas Pengendara Kendaraan Bermotor pada Saat Mudik Mebaran. Bidang Hukum INFO Singkat, XI(11), 1-6. Retrieved from http://berkas.dpr.go.id/puslit/files/info_singkat/Info Singkat-XI-11-I-P3DI-Juni-2019-208.pdf

Fatah, Z. (2019). Jurnal "Kajian Hasil Penelitian Hukum." Journal of Chemical Information and Modeling, 3(1), 596-608. https://doi.org/10.1017/CBO9781107415324.004

Hidayah, A. (2017). Ensiklopedia Traffic Signs: Solusi Cerdas Memperkenalkan Road Safety Culture pada Anak Sekolah. Jurnal Penelitian Dan Penalaran, 4(1), 688-700. Retrieved from https://media.neliti.com/media/publications/248332-none-c6409c7f.pdf

Mamudji, S. (2006). Penelitian Hukum Normatif. Jakarta: PT. Raja Grafindo Persada.

Marsaid, Hidayat, M., \& Ahsan. (2013). Faktor yang Berhubungan dengan Kejadian Kecelakaan Lalu Lintas pada Pengendara Sepeda Motor di Wilayah Polres Kabupaten Malang. Jurnal Ilmu Keperawatan, 1(2). Retrieved from https://media.neliti.com/media/publications/99488-ID-faktoryang-berhubungan-dengan-kejadian.pdf

Mertokusumo, S. (1986). Hukum Mengubah. Jogjakarta: Siberty.

Nurdjanah, N., \& Puspitasari, R. (2017). Faktor yang Berpengaruh terhadap Konsentrasi Pengemudi Factors. 29(1), 141-157. Retrieved from https://www.researchgate.net/publication/323819834_Faktor_yang_Berpengaruh_terhadap_Kon sentrasi_Pengemudi/link/5aac72d80f7e9b4897bc9a59/download

Poernomo, B. (2002). Dalam Asas-Asas Hukum Pidana. Jakarta: Ghalia Indonesia.

Putri, C. E. (2014). Analisis Karakteristik Kecelakaan dan Faktor Penyebab Kecelakaan Pada Lokasi Blackspot di Kota Kayu Agung. Teknik Sipil Dan Lingkungan, 2(1), 154-161. Retrieved from https://media.neliti.com/media/publications/211745-analisis-karakteristik-kecelakaan-dan-fa.pdf

Saputra, A. D. (2017). Studi Tingkat Kecelakaan Lalu Lintas Jalan di Indonesia Berdasarkan Data KNKT ( Komite Nasional Keselamatan Transportasi ) Dari Tahun 2007-2016. Warta Penelitian Perhubungan, 29(2), 179-190. Retrieved from http://ojs.balitbanghub.dephub.go.id/index.php/warlit/article/download/557/319

Setyowati, D. L., Firdaus, A. R., \& Rohmah, N. (2018). Faktor Penyebab Kecelakaan Lalu Lintas pada Siswa Sekolah Menengah Atas di Kota Samarinda. The Indonesian Journal of Occupational Safety and Health, 7(3), 329-338. https://doi.org/10.20473/ijosh.v7i3.2018.329

Tahir, A. (2005). Angkutan Massal sebagai Alternatif Mengatasi Persoalan Kemacetan Lalu Lintas Kota Surabaya. Jurnal SMARTek, 3(3), 1-14. Retrieved from http://jurnal.untad.ac.id/jurnal/index.php/SMARTEK/article/view/365

Yusrizal. (2016). Survey Penggunaan Teknologi Informasi dan Komunikasi di Wilayah Perbatasan. Jurnal Teknologi Informasi Dan Komunikasi Informasi Dan Komunikasi, 5(1), 13-28. Retrieved from https://jurnal.kominfo.go.id/index.php/jtik/article/download/784/451

Kitab Undang-Undang Hukum Pidana

Peraturan Pemerintah Nomor 37 Tahun 2017 Tentang Keselamatan Lalu Lintas dan Angkutan Jalan Undang-Undang Dasar Negara Republik Indonesia 1945

Undang-Undang Nomor 22 Tahun 2009 Tentang Tentang Lalu Lintas dan Angkutan Jalan 